\title{
Climatic trends in Cameroon: implications for agricultural management
}

\author{
Ernest L. Molua* \\ Department of Economics \& Management, University of Buea, PO Box 63, Buea, South West Province, Cameroon
}

\begin{abstract}
The weather in Cameroon, an ecologically diverse country in central Africa, is determined by equatorial and tropical air masses. Agricultural production is predominantly rain-fed, and the semi-extensive farming systems are particularly sensitive to small changes in climatic conditions. To estimate the relevance of climate issues for farmers' livelihoods, time series techniques were employed to analyse real temperature and precipitation series for 1960-2000 at selected weather stations across Cameroon. Strong positive temperature trends exist for the months of July, August and September. Significant trends in precipitation are observed at Kribi and Douala in the coastal region, and Batouri in the forest savanna ecotone; marginally significant trends occur in Mamfe in the rainforest and Bafoussam in the Guinean savanna zone. The results indicate that locally increasing temperatures are linked to increasing dryness and drought. Management of Cameroon's agrarian economy will require improved monitoring and forecasting, a shift toward more drought-resistant crops and varieties, adaptation of planting methods, and implementation of water conservation techniques.
\end{abstract}

KEY WORDS: Cameroon · Climate variation · Trend analysis · Agrarian economy Resale or republication not permitted without written consent of the publisher

\section{INTRODUCTION}

Cameroon offers an almost complete range of intertropical climates, which are influenced by the Harmattan and the Atlantic Monsoon winds. The varied relief and the coastal setting also introduce climate gradation, due to the effects of mountains and the sea. Located on the Gulf of Guinea, Cameroon comprises 2 principal climatic zones: the equatorial zone and the tropical zone. The equatorial zone stretches from 2 to $5^{\circ} \mathrm{N}$, covering the southern and the mountainous western part of the country, with 4 seasons ( 2 dry and 2 wet seasons) annually. Its climate corresponds to the classical Guinean region, with the following subtypes: (1) The seaboard, e.g. Kribi, with abundant rainfall (2200 $\mathrm{mm} \mathrm{yr}^{-1}$ ) and only 2 mo (January and February) receiving $<100 \mathrm{~mm}$ of rainfall. (2) The inland areas, e.g. Yaounde, with moderate temperatures (mean: $23^{\circ} \mathrm{C}$ ) and total rainfall $<1540 \mathrm{~mm}$, with a 'small' dry season. This climate subtype prevails over the southern part of the South Cameroon Plateau, extending into the east of the country around Batouri. (3) North of $5^{\circ} \mathrm{N}$, the Guinean-Sudanese subtype differs from the 'inland' type by its lack of a 'small' dry season, whereas the 'big' dry season becomes longer, with minimum rainfall in December and January.

The diversity of climate in Cameroon makes it suitable for studying climate variation and climate change. Changing weather conditions such as higher temperatures and variations in precipitation can result in significant impacts on agriculture, forestry and rural livelihoods (e.g. UNEP/GEF 2000). It is therefore important to examine the significance of changes in monthly temperature and precipitation. In assessing the statistical evidence of significant trends in temperature and precipitation in Cameroon, the climate series are expressed as a deterministic function of time.

\section{TREND ANALYSIS OF TEMPERATURE AND PRECIPITATION}

Rainfall and temperature time series exhibit stochastic behaviour. Empirical studies reveal that some time series data contain deterministic trends, while others are stationary (e.g. Carlino \& Mills 1993, Stern \& Kauf- 
mann 1997, Hobijn \& Franses 2000). Upward trends in temperature can be taken as evidence of global warming (e.g. Bloomfield 1992, Wibig \& Glowicki 2002). Debates about the reality and magnitude of global climate change have motivated these and other studies, including Bloomfield \& Nychka (1992) and Woodward et al. (1997), designed to test for deterministic trends in climate datasets. Statistical evidence of climate trends based on real climate datasets will help in predicting details of climate change and in managing agricultural adaptation.

In the present time series model, the hypothesis of increasing temperature and precipitation trends associated with global climate change was tested using data of weather stations across Cameroon. Considering the series $S_{t}$,

$$
S_{t}=\beta_{0}+\beta_{1} t+\omega^{*} S_{t-1}+\mu_{t}
$$

where $S_{t}$ is the time series (e.g. temperature or precipitation), $t$ is the time index; $\beta_{0}, \beta_{1}$ and $\omega^{*}$ are the regression coefficients (parameters), $\mu_{t}$ is error (a stationary zero mean process) and $\beta_{0} \neq 0$. Two possible types of trends (stochastic and/or deterministic) can appear in Eq. (1) if $\beta_{1} \neq 0$ and $\omega^{*}=0$; a deterministic trend (trendstationary process) cannot be cointegrated with a stochastic (difference-stationary) process (Lloyd \& Rayner 1993): a stochastic process cannot be deterministic. One can attempt to differentiate between the two visually given a large data set. Whereas a deterministic trend will move monotonically upwards or downwards over time, the stochastic trend is typically characterized by long upward and downward swings (Lloyd \& Rayner 1993).

$$
S_{t}=\beta_{0}+\beta_{1} t+\mu_{t}
$$

Eq. (2) represents a deterministic trend. $S_{t}$ may trend upwards or downwards, depending on the sign of $\beta_{1}$. For a temperature (or precipitation) series, a positive $\beta_{1}$ will imply a warming (or desiccation) trend; such a deterministic trend is possibly predictable. If however, $\beta_{1}=0$ and $\omega^{*}=1$, then Eq. (1) becomes,

$$
\Delta S_{t}=\beta_{0}+\mu_{t}
$$

This is a stochastic trend. $S_{t}$ may drift upwards or downwards, depending on the sign of $\beta_{0}$. Stern \& Kaufmann (1997), using the tests of Phillips \& Peron (1998) and Schmidt \& Phillips (1992), have shown that temperature series may be trend stationary, i.e. they may have a deterministic trend. Therefore, if Eq. (2) is estimated by ordinary least squares (OLS) and the error term is white noise, then we may test for a deterministic trend, e.g. by examining the $t$-ratio on the time trend associated with $\beta_{1}$. The $t$-ratio is compared with critical values derived by a Monte Carlo simulation (see Dickey \& Fuller 1981).

There are, however, concerns with limitations of the Dickey-Fuller approach, especially in (1) distinguishing between unit roots with a drift and a linear trend, (2) potential serial correlations amongst the error terms, and (3) the low power of the Dickey-Fuller tests. Testing for the significance of the trend term under the assumption that the error term is a white noise when in fact it is serially correlated or a unit root, will bias the test in favour of finding a trend (Woodward et al. 1997, Clark et al. 2000). The test for the existence of a unit root in a time series using the Dickey-Fuller test depends on whether or not one includes a trend in the model (Vogelsang 1998). Since the Dickey-Fuller approach is conditioned on whether or not a trend is included in the empirical model, it is difficult to know whether this hypothesis is being tested when one tests for unit root in a time series model (Clark et al. 2000). Following Dickey-Fuller, we could account for shortrun dynamics in Eq. (1) and add an appropriate number of lag first differences to the equation: $\Delta S_{t}=\beta_{1} t+\delta S_{t-1}+\sum_{t=1}^{k} \beta_{i 1} \Delta S_{t-1}+\varepsilon_{t}$ when $k$ is chosen to induce white-noise residuals, $\varepsilon_{i i}$. If $\beta_{1}=0$ and $\delta=0, S_{t}$ is a difference stationary process, i.e $S_{t} \sim I(1)$ and $\Delta S_{t} \sim$ $I(0)$ (see discussion in Lloyd \& Rayner 1993). However, this approach reduces the sensitivity of the findings.

This study accounted for these limitations by (1) employing the trend analysis of Vogelsang \& Franses (2001), to determine whether there are trends in temperature and precipitation, and (2) testing to ascertain if the error terms are serially correlated. Therefore, assuming Eq. (2) is a trend stationary process, Eq. (2) was estimated by OLS and the Durbin-Watson technique employed to test for autocorrelation. Testing for a deterministic trend was by comparing the $t$-ratio to the $t$-statistic generated through the Monte Carlo simulation in Vogelsang \& Franses (2001, their p. 7 \& 17).

Table 1. Weather stations included in this study (data from author's survey 2001)

\begin{tabular}{|lcccccccr|}
\hline & $\begin{array}{c}\text { Lat. } \\
(\mathrm{N})\end{array}$ & $\begin{array}{c}\text { Long. } \\
(\mathrm{E})\end{array}$ & $\begin{array}{c}\text { Elevation } \\
(\mathrm{m})\end{array}$ & $\begin{array}{c}\text { Rainy } \\
\text { days }\left(\mathrm{yr}^{-1}\right)\end{array}$ & $\begin{array}{c}\text { Rainfall } \\
\left(\mathrm{mm} \mathrm{yr}^{-1}\right)\end{array}$ & \multicolumn{2}{c|}{$\begin{array}{c}\text { Temperature }\left({ }^{\circ} \mathrm{C}\right) \\
\text { Mean Max. Min. }\end{array}$} \\
\hline Maroua & $10^{\circ} 27^{\prime}$ & $14^{\circ} 15^{\prime}$ & 423 & 56 & 850 & 26 & 45 & 11 \\
Ngaoundere & $7^{\circ} 21^{\prime}$ & $13^{\circ} 33^{\prime}$ & 114 & 80 & 1510 & 22 & 38 & 7 \\
Batouri & $4^{\circ} 25^{\prime}$ & $14^{\circ} 24^{\prime}$ & 647 & 105 & 1640 & 23 & 37 & 11 \\
Yaoundé & $3^{\circ} 49^{\prime}$ & $11^{\circ} 31^{\prime}$ & 752 & 90 & 1540 & 21 & 35 & 12 \\
Bafoussam & $5^{\circ} 37^{\prime}$ & $10^{\circ} 45^{\prime}$ & 1210 & 110 & 2170 & 20 & 33 & 12 \\
Douala & $4^{\circ} 00^{\prime}$ & $09^{\circ} 44^{\prime}$ & 9 & 250 & 3810 & 26 & 37 & 17 \\
Kribi & $2^{\circ} 57^{\prime}$ & $09^{\circ} 54^{\prime}$ & 15 & 115 & 2200 & 25 & 40 & 16 \\
Mamfe & $5^{\circ} 43^{\prime}$ & $09^{\circ} 16^{\prime}$ & 126 & 170 & 1851 & 25 & 35 & 15 \\
\hline
\end{tabular}




\section{DATABASE DEVELOPMENT AND ESTIMATION PROCEDURES}

Monthly data on precipitation and temperature were obtained for 1960-2000.

\subsection{Precipitation data}

Mean monthly and annual precipitation at each station were computed using the daily records and monthly totals, respectively. The spatial distribution of rainfall was interpolated by area-average normalization (Kraus 1977). The weather data are summarized in Table 1. Temperatures are lowest around August and September, and highest between February and April (Fig. 1). Rainfall peaks in July, August and September, and the lowest rainfall is observed between December and February (Fig. 2). Precipitation anomalies (departure from the mean divided by standard deviation, i.e. $\Delta R F_{j}=\frac{R F_{j}-R \bar{F}}{\sigma}$, where $\Delta R F_{j}$ is rainfall variation and $R \bar{F}$ is the mean) are plotted in Fig. 3; the years 1962, 1971 and 1989 experienced the highest, and 1987, 1988 and 1990 had the lowest rainfall anomalies. Climate variation in Cameroon can be ascertained by comparison with other African regions (Fig. 4): the Sahel displays large multidecadal variability with recent desiccation; East Africa demonstrates a relatively stable regime with some increase in rainfall; $\mathrm{SE}$ Africa exhibits inter-decadal variability (Hulme et al. 2001).

\subsection{Temperature data}

Temperature anomalies in Cameroon were computed in the same way as precipitation anomalies. The years 1971 and 1974-1976 were relatively cold, whilst 1969, 1988 and 1998 were relatively warm (Fig. 5). The 1990s has been the warmest decade so far; Hulme et al. (2001) have shown that temperatures in East Africa, SE Africa and the Sahel were higher during the 1990s than they were earlier in the century, and are currently between 0.2 and $0.3^{\circ} \mathrm{C}$ warmer than the 1961 average (Fig. 6), having risen by $0.05^{\circ} \mathrm{C}$ per decade during the 20th century; warming is highest in June to November.

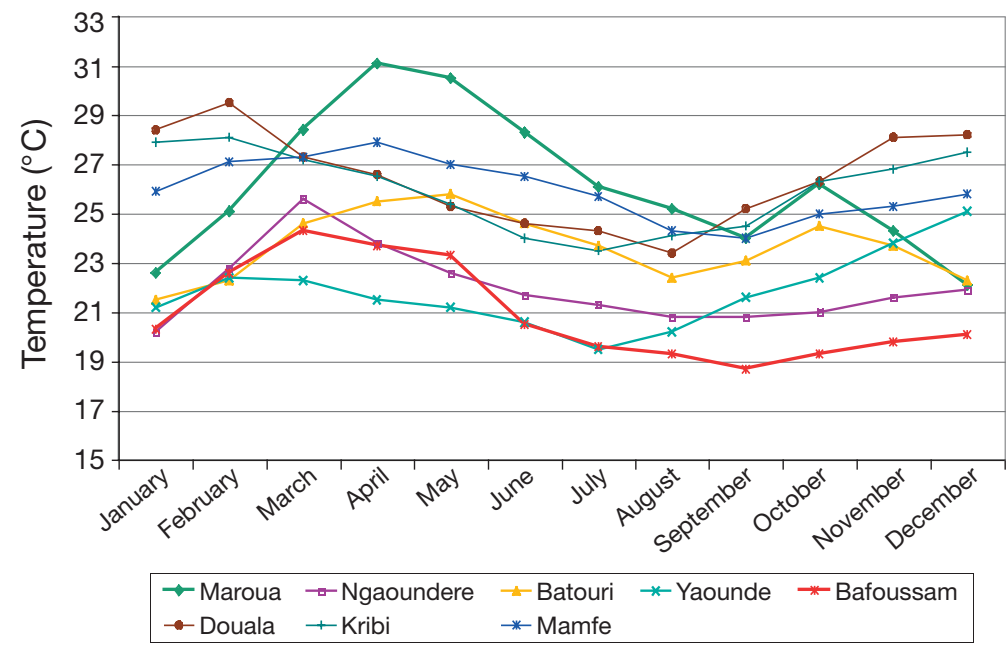

Fig. 1. Mean monthly temperatures across Cameroon (1961-2001)

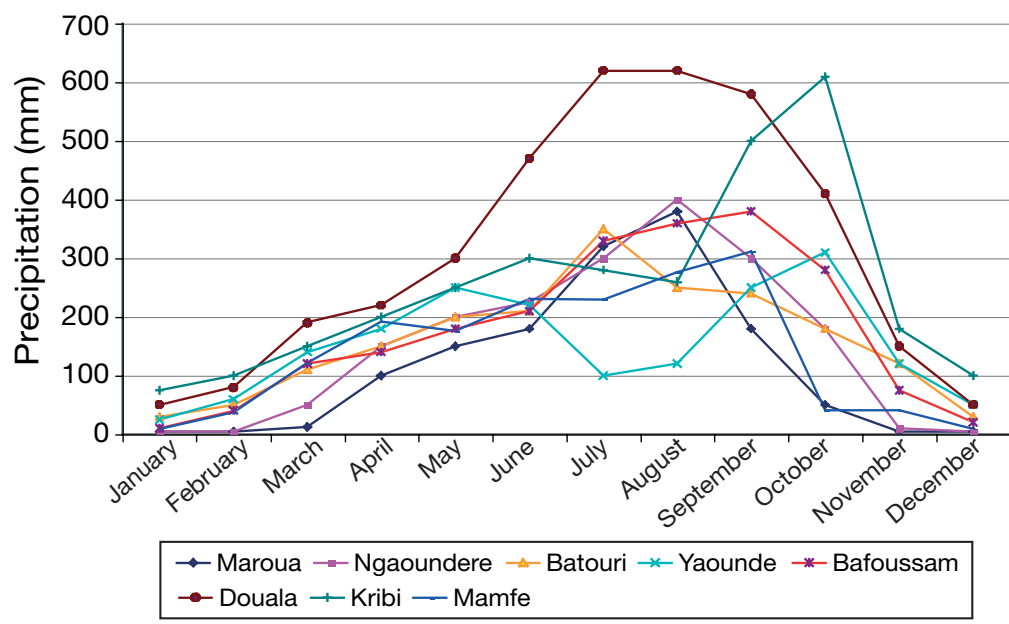

Fig. 2. Mean monthly precipitation across Cameroon (1961-2001)

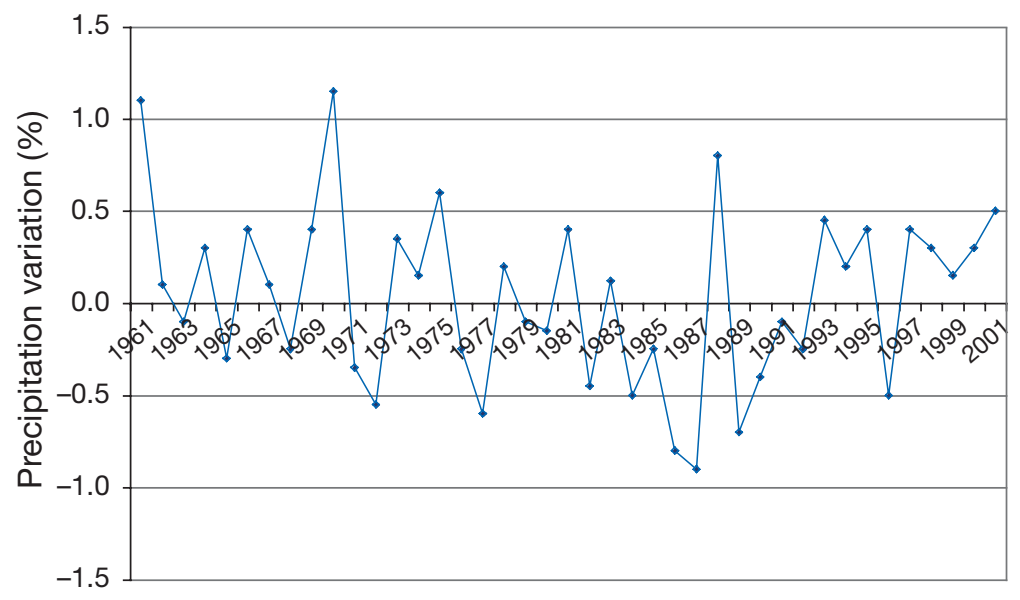

Fig. 3. Mean precipitation anomalies (\%) in Cameroon 


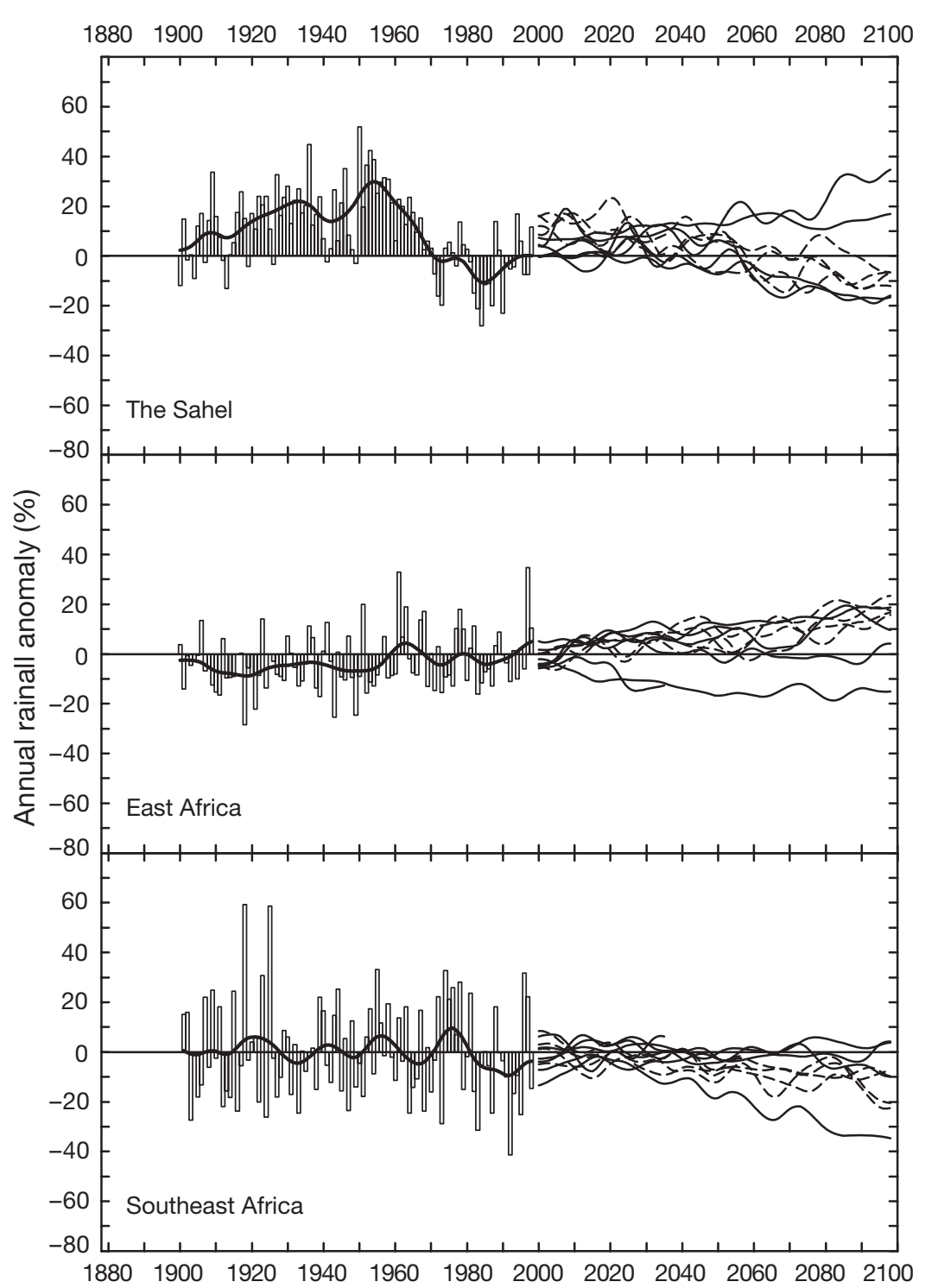

Fig. 4. Rainfall anomalies for 3 African regions (1900-1998), and modelsimulated anomalies (2000-2099); anomalies are expressed with respect to observed or model-simulated 1961-1990 average rainfall (from Hulme et al. 2001)

Models suggest that warming will accelerate, so that Africa will be 2 to $6^{\circ} \mathrm{C}$ warmer by the end of the $21 \mathrm{st}$ century.

\section{TRENDS IN TEMPERATURE AND PRECIPITATION}

\subsection{Monthly trends}

Point estimates of the $\beta_{i}$ coefficients (Eq. 2) are reported in Table 2, together with Durbin-Watson measurements for serial correlation in the residuals and the $t$-test for significance of the parameter esti- mates. Point estimates are all positive, with the strongest trends in March and April. The estimate of $\beta_{i}$ for March $(0.0021)$ suggests an increase by $0.0021^{\circ} \mathrm{C}$ $\mathrm{yr}^{-1}$, or 0.21 degrees per century. This is lower than the annual global increase in temperature, which has been consistently estimated in the range of 0.004 to $0.007^{\circ} \mathrm{C}$ (see Bloomfield 1992, Woodward \& Gray 1993, Zheng \& Basher 1999, Fomby \& Vogelsang 2000, Vogelsang \& Franses 2001). None of the estimates in this study are closer to the annual global rate. Some empirical studies of global temperature trends, using autoregressive and spectral analysis, suggest the existence of a rising trend in global climate series (Bloomfield 1992, Bloomfield \& Nychka 1992, Gabraith \& Green 1992), and have assessed the impact of global climate change to be considerable (Jones et al. 1986, Hansen \& Lebdeff 1987). Other studies, however, conclude that the magnitude of global warming is generally small (e.g. Balling \& Idso 1999, Barnett \& Schlesinger 1987 , Wibig \& Glowicki 2002).

Woodward et al. (1997) argued that when there is strong to moderate correlation in regression residuals, the parameter estimate can have excessive actual significance levels, thus erroneously finding a significant rend in the series. The Durbin-Watson test statistics do not suggest autocorrelation among the residuals. The Breusch (1978) and Godfrey (1978) test, which was conducted as well (results not reported), does not suggest autocorrelation among the residuals either. The slopes for temperature are significant for March, April, June, November and December (Table 2), suggesting that Cameroon has experienced warming in those months. None of the estimates is negative, thus highlighting the absence of cooling over the last $40 \mathrm{yr}$.

In the precipitation series (Table 2) the largest positive trends are in July, August and September. January and February have negative trends. The significant point estimates suggest increased wetting in Cameroon in July to October (i.e. during the second wet season), but not in the first wet season (March to June). Increased dryness in December to February could delay the onset of the rainy season. The estimates indicate pronounced seasonality. The rainy seasons have become wetter, and the dry periods drier. Overall, the current findings add credence to the evidence on 
African climate assembled by Bonnefille et al. (1990), Schlesinger et al. (1990), Hulme (1996a,b), Hulme et al. (2001) and Nicholson (2001).

\subsection{Station and regional trend analysis}

The hypothesis of increasing regional temperature was tested using actual temperature data for 8 weather sites, spatially distributed across Cameroon. Results of the analysis using the trend test for the climate time series are summarized in Table 2. Significant trends in temperature were found at 5 locations, in particular at Maroua, Ngaoundere and Mamfe ( $p=0.01)$. Whilst Maroua is located in the dry Sahel and Ngaoundere in the dry savannah region, Yaounde on the other hand (in the humid region) is a case of marginal warming.

In contrast to the temperature results, significant trends in precipitation were observed at Kribi and Douala ( $\mathrm{p}=0.01)$, at Batouri ( $\mathrm{p}=$ $0.05)$, as well as a marginally significant trend at Mamfe and Bafoussam ( $p=0.1$ ). Unpredictable weather, limited and erratic rainfall and nutrient-poor soils are major ecological limitations for agriculture in the northern region represented by Maroua. The inter- and intra-annual variability in rainfall is a major factor that determines the success of agriculture in this region, and a survey of farming communities has shown that farmers complain that the rainy seasons are now starting later than usual and have less than average rainfall (Molua 2002). Although most farmers have traditional knowledge of rainfall patterns, they are often taken by surprise by changes in the 'normal' rainfall patterns, particularly if a run of wet years is followed by one of dry years. Inter-annual variability in precipitation can lead to marked reductions in agricultural output, particularly in the drier regions.

Therefore, climate change across Cameroon over the 1960-2000 period depends on geography and relief. In line with the findings of UNEP/GEF (2000), increased precipitation levels and extreme variation may cause damage in the southern coastal districts (temperature and precipitation changes at Douala and

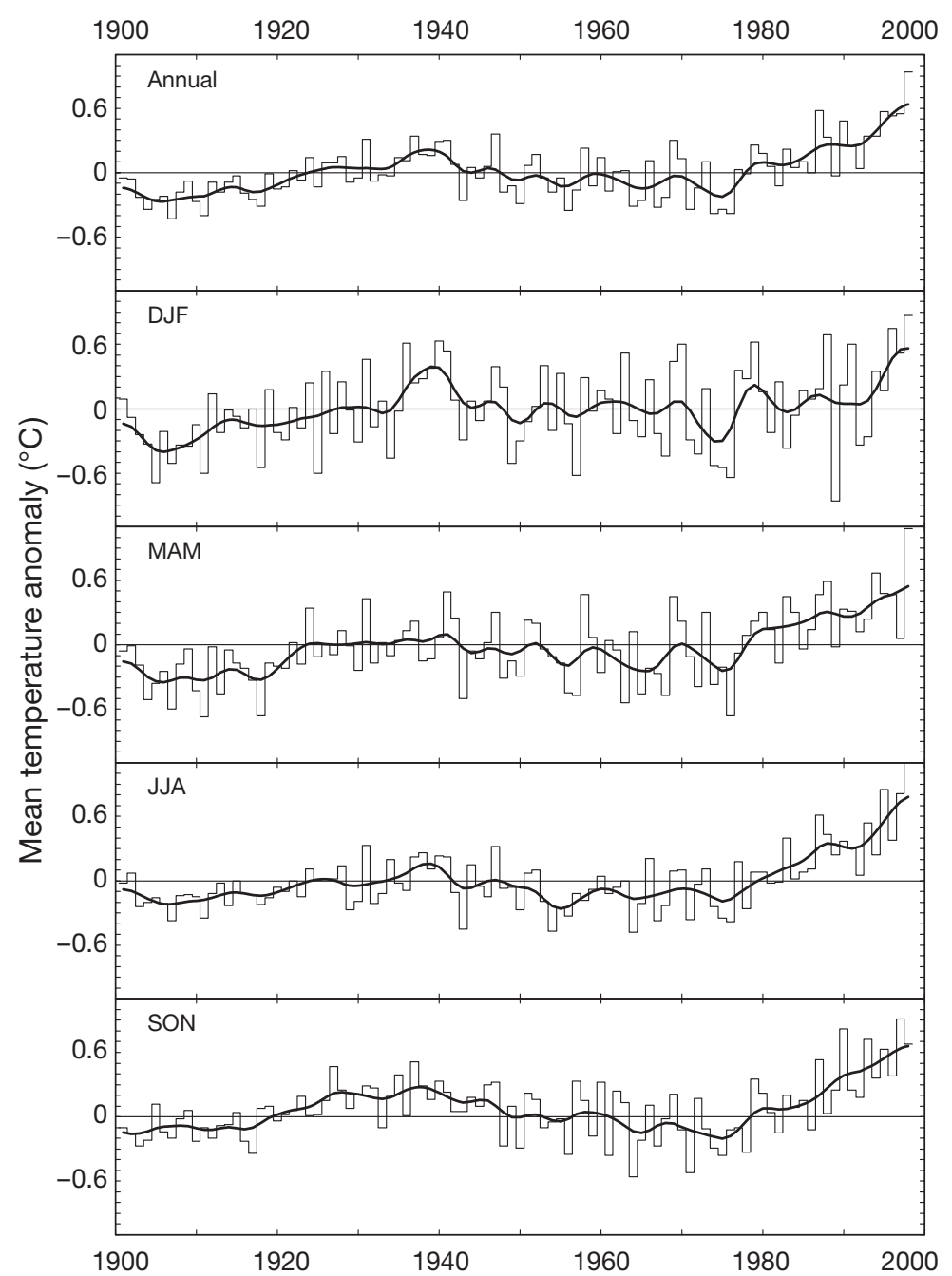

Fig. 6. Mean surface air temperature anomalies for the African continent, 1901-1998, expressed with respect to 1961-1990 average (from Hulme et al. 2001) 
Table 2. Trend analysis for monthly temperature and precipitation in Cameroon (1961-2001). ( $\beta_{i}$ is a coefficient, DW is the Durbin-Watson statistic). ${ }^{* * *} \mathrm{p}=0.01,{ }^{* *} \mathrm{p}=0.05,{ }^{*} \mathrm{p}=0.1$ (2-tailed $t$-test; Vogelsang \& Franses 2001, Table I, p. 17)

\begin{tabular}{|c|c|c|c|c|c|c|}
\hline & \multicolumn{3}{|c|}{ Temperature } & \multicolumn{3}{|c|}{ Precipitation } \\
\hline & $\begin{array}{c}\beta_{i} \\
\left({ }^{\circ} \mathrm{C} \mathrm{yr}^{-1}\right)\end{array}$ & $t$ & DW & $\begin{array}{c}\beta_{i} \\
\left(\mathrm{~mm} \mathrm{yr}^{-1}\right)\end{array}$ & ) & DW \\
\hline \multicolumn{7}{|l|}{ Month } \\
\hline January & 0.0003 & 1.0124 & 2.0516 & -0.0025 & $-3.6529^{*}$ & 1.9900 \\
\hline February & 0.0001 & 1.2000 & 1.7215 & -0.0021 & $-3.4954^{*}$ & 1.8720 \\
\hline March & 0.0021 & $7.5990^{* * *}$ & 1.8331 & 0.0002 & 1.3626 & 1.5290 \\
\hline April & 0.0020 & $8.2861^{* * *}$ & 1.8549 & 0.0004 & 0.5163 & 1.8549 \\
\hline May & 0.0006 & 0.5552 & 1.6522 & 0.0007 & 2.5552 & 1.5631 \\
\hline June & 0.0013 & $4.8537^{* *}$ & 1.3539 & 0.0005 & 0.8537 & 1.9828 \\
\hline July & 0.0007 & 0.9663 & 1.6781 & 0.0031 & $7.5610^{* * *}$ & * 1.8418 \\
\hline August & 0.0005 & 1.0023 & 1.7217 & 0.0043 & $7.9451^{* * *}$ & * 1.9128 \\
\hline September & 0.0002 & 0.5691 & 1.5689 & 0.0068 & $8.0121^{* * *}$ & * 2.2689 \\
\hline October & 0.0008 & 0.7415 & 1.6344 & 0.0018 & $4.6419^{* *}$ & 2.0445 \\
\hline November & 0.0013 & $3.3201^{*}$ & 2.1130 & 0.0002 & 1.8830 & 1.7710 \\
\hline December & 0.0011 & $3.373^{*}$ & 1.9351 & 0.0001 & 1.0018 & 1.9655 \\
\hline \multicolumn{7}{|l|}{ Station } \\
\hline Maroua & 0.0042 & $8.3904^{* * *}$ & 1.805 & 0.0001 & 0.7414 & 1.3160 \\
\hline Ngaoundere & 0.0038 & $7.8812^{* * *}$ & 1.543 & 0.0001 & 1.8730 & 1.3 .571 \\
\hline Batouri & 0.0001 & 1.6503 & 1.238 & 0.0041 & $3.9310^{*}$ & 1.8290 \\
\hline Bafoussam & 0.0022 & $4.5682^{* *}$ & 1.934 & 0.0025 & 2.5454 & 1.5226 \\
\hline Yaounde & 0.0024 & $4.9610^{* *}$ & 1.615 & 0.0002 & 1.8235 & 1.4642 \\
\hline Douala & 0.0003 & 1.7310 & 1.204 & 0.0090 & $8.1318^{* * *}$ & * 2.0463 \\
\hline Kribi & 0.0002 & 0.9802 & 1.237 & 0.0061 & $7.8611^{* * *}$ & * 1.9980 \\
\hline Mamfe & 0.0045 & $7.5212^{* * *}$ & 2.008 & 0.0024 & $3.3501^{*}$ & 1.7090 \\
\hline
\end{tabular}

\section{AGRICULTURAL MANAGEMENT}

Warming in Cameroon has been greatest during the dry season, especially in November, December, March and April. There has been an overall decline of nearly $5 \%$ in rainfall across the country, even though July, August and September exhibit precipitation increases. Some periods (1969-1970 and 1988-1990) have been much wetter than average; changes in weather patterns, especially in rainfall, have had pronounced effects on food availability and on the income of agricultural households (Molua 2002). The late 1980s witnessed probably the driest period, with 2 episodes of mild drought in the northern part of the country, where recurrent mild drought is almost a permanent feature, affecting both agriculture and wildlife, and causing malnutrition and mortality. These drought events led to lower returns to agriculture (Fig. 7). In the rainforest parts of the country, heavy annual rainfall (1500 to $4000 \mathrm{~mm}$ ) and average annual temperature of $25^{\circ} \mathrm{C}$ with fluctuations of only of 1 to $3^{\circ} \mathrm{C}$, and a humidity of $>80 \%$ at all seasons is ideal for a range of crops. Tubers such as Kribi), whilst dry areas in the northern (Sahel) part of the country would be damaged by increased temperatures (e.g. Maroua). The long-term productivity and competitiveness of the region's agriculture is at risk if increased warming aggravates drought in the Sahel.

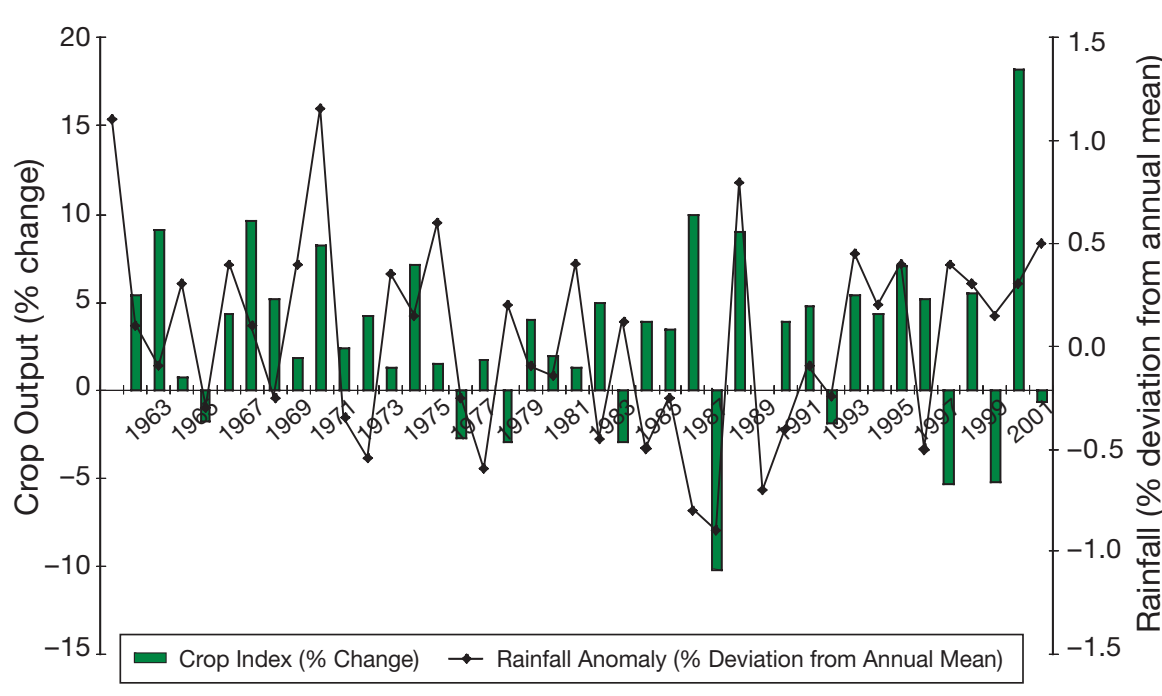

Fig. 7. Crop production and rainfall in Cameroon cocoyam and cassava dominate the crop mix. Maize and groundnuts are also cultivated, but in smaller quantities meant only for household use.

The drier sudano-sahelian zone typified by the northern provinces of the country is host to dry land agriculture dominated by sorghum, millet, groundnut, cotton, and rice grown along river banks. Temperatures over the year are very high, with an average of $28^{\circ} \mathrm{C}_{i}$ temperatures are highest in April, with a monthly average of $40^{\circ} \mathrm{C}$, and January has the lowest monthly average, $26^{\circ} \mathrm{C}$. December, January and February experience no rainfall, while August is highest with about $200 \mathrm{~mm}$ of rainfall. These climatic differences across the country influence the distribution of crops grown in the country. Some crop types and varieties perform better in one region than others. In the dry north, only a few crops excel in the harsh climatic conditions.

In the grassland savanna belt within the West and Northwest provinces with an average annual 
rainfall of $2500 \mathrm{~mm}$, roots and tubers (sweet potatoes, yams, cocoyams), cereals and indigenous vegetables dominate. The mean monthly rainfall varies from month to month with the highest peaks between April and September. Temperature decreases as both latitude and altitude increase, and is influenced by the degree of cloudiness. Average annual temperature is about $19^{\circ} \mathrm{C}$. Low and high temperatures are, respectively, 16 and $30^{\circ} \mathrm{C}$ in January, 19 and $28^{\circ} \mathrm{C}$ in April, 21 and $33^{\circ} \mathrm{C}$ in July and 19 and $25^{\circ} \mathrm{C}$ in October. These variations influence the type of crops grown.

The warming trend in recent years could reduce the yields of major food staples such as cereals, and a significant increase in growing season temperatures will require shifts to new varieties that are more heat tolerant, do not mature too quickly, and have a higher temperature optimum for photosynthesis. This is because most plant processes related to growth and yield are temperature dependent. The challenge therefore for future research is to gauge the possible impact of future temperature increases on crops in tropical regions such as Cameroon, where current temperature levels are already near the threshold of the optimum range.

While temperature is highly significant, water supply is usually the most critical factor controlling the yield of crops. The effects of water shortages on production may vary according to the crop involved, the soil characteristics, the root system, and the severity and timing of shortages in relation to the growth cycle. Reliability of rainfall, particularly at critical phases of plant development, accounts for much of the variation in agricultural potential. Moisture stress during flowering, pollination and grain filling is harmful to staple crops such as maize, soybean and cowpeas. Hence, inter-annual or inter-seasonal rainfall variability represents a major challenge to the rain-dependent agricultural producers in Cameroon (Molua 2003).

The demand for water for irrigation in Cameroon is projected to rise in a warmer climate, leading to increased competition between agriculture and non-agriculture uses for water, and to falling water tables. Global warming will thus surely impact regional water sources and river flow regimes. If this is associated with reduced water holding capacity of the soils, then increased water run-off during the wet season would result in high flow rates. Water lost to run-off may increase deficits during rainy seasons and thus increase the duration and intensity of dry seasons. Intensified evaporation may further increase the hazard of salt accumulation in the soil. This may disrupt growing conditions and result in crop failures, with serious implications for food security and agricultural productivity.

In Cameroon there is no routine use of scientific climate forecasts for the agricultural systems, and early warning systems are inadequate; climate information is obtained from diverse sources that encompass knowledge from grandparents, neighbours in the community, neighbours from other communities, natural indicators (e.g. wind directions), biological indicators (flowering of bushes, behavior of birds and other animals), technical staff of various institutions, and some information from radio and television. Many farmers base their decisions on supernatural omens (e.g. dreams, religious interpretations).

Empirical observations in different agro-ecologies in Cameroon reveal varied forms of adaptation to the impacts of climate change. At the farm level, preseason decisions that take changed possibilities of seasonal climate into account include crop type (e.g. drought-tolerant sorghum versus moisture-dependent maize), variety (early-maturing for drought avoidance versus late maturing for wetter seasons), planting density (low density if rainfall may be scarce versus high density if rainfall is predicted to be more plentiful), and fertilizer inputs (lower levels of application in droughtpredicted seasons versus higher levels to take advantage of good seasons). In addition, mid-season corrections include the thinning of a densely planted crop if soil moisture becomes limiting. After the growing season, decisions are modified in terms of marketing and storage. Climate change also influences the manner in which the manufacturing sector plans input production, prepares for the provision of credit and crop insurance, and affects transportation of both inputs and outputs. At the national level, policy decisions such as water resource planning by regional and national planners are also affected by varying and changing climate, especially during and after the growing season.

\section{CONCLUDING REMARKS}

The economy of Cameroon depends strongly on agriculture; therefore, the effects of global warming and climate change are likely to threaten both the welfare of the population and the economic development of the country. Agricultural policy should prepare for changing climate hazards through (1) reducing vulnerability, (2) developing monitoring and (3) enhancing the responsiveness of the agricultural sector to forecasts of production variations and possibly food crises. Farmers need assistance in adapting their farm management to the changing climate. Government irrigation policy, for instance, must account for reduced precipitation and drier conditions in the northern part of the country, and wetter and more variable conditions in the south. Otherwise, climate change will cause increasing socioeconomic costs. 


\section{LITERATURE CITED}

Balling RC Jr, Idso SB (1990) Effect of greenhouse warming on maximum summer temperature. Agric For Meteorol 53: 143-147

Barnett TP, Schlesinger ME (1987) Detecting changes in global climate induced by greenhouse gases. J Geophys Res 93:14772-14780

Bloomfield P (1992) Trends in global temperature. Clim Change 21(1):1-6

Bloomfield P, Nychka D (1992) Climate spectra and detecting climate change. Clim Change 21(3):275-287

Breusch T (1978) Testing for autocorrelation in dynamic linear models. Aust Econ Pap 17:334-355

Carlino GA, Mills LO (1993) Are US regional incomes converging? J Monet Econ 32:335-345

Clark JS, Yiridoe EK, Burns ND, Astakie T (2000) Regional climate change: trend analysis of temperature and precipitation series in selected Canadian sites. Can J Agric Econ 48:27-38

Dickey DA, Fuller WA (1979) Distribution of the estimators of autoregression processes. J Am Stat Assoc 74:427-431

Dickey DA, Fuller WA (1981) Likelihood ratio statistics of autoregressive time series with a unit root. Econometrica 49(4):1057-1072

Fomby T, Vogelsang TJ (2000) The application of size robust trend analysis to global warming temperature series. Mimeograph of Economics, Cornell University, Ithaca, NY

Galbraith J, Green C (1992) Inference about trend in global temperature data. Clim Change 22(3):209-221

Godfrey LG (1978) Testing for higher order serial correlation in regression equations when the regressors contain lagged dependent variables. Econometrica 46:1303-1310

Hansen J, Lebedeff S (1987) Global surface air temperature. J Geophys Res 92:13345-13372

Hobijn B, Franses PH (2000) Asymptotically perfect and relative convergence of productivity. J Appl Econometrics 15: 59-81

Hulme M (ed) (1996a) Climate change and Southern Africa: an exploration of some potential impact and implications in the SADC region. Climate Research Unit, University of East Anglia, and WorldWide Fund for Nature, Norwich, UK

Hulme M (1996b) Climate change within the period of meteorological records. In: Adams WM, Goude AS, Orme AR (eds) The physical geography of Africa. Oxford University Press, Oxford, p 88-102

Hulme M, Doherty R, Ngara T, New M, Lister D (2001) African climate change: 1900-2100. Clim Res 17:145-168

Jones PD, New M, Martin S, Rigor IG (1999) Surface air temperature and its changes over the past 150 years. Rev Geophys 37(2):173-199

Kraus EB (1977) Sub-tropical droughts and cross-equatorial transport. Mon Weather Rev 105:1009-1018

Editorial responsibility: Otto Kinne,

Oldendorf/Luhe, Germany
Landsea CW, Gray WM (1992) The strong association between western sahel monsoon rainfall and intense Atlantic hurricanes. J Clim 5:435-453

Lloyd TA, Rayner AJ (1993) Cointegration analysis and the determinants of land prices: comment. J Agric Econ 44(1): 149-156

Lynch SD, Schulze RE (1995) Techniques for estimating areal daily rainfall. Working Paper, Department of Agricultural Engineering, University of Natal. Available at: http:// gis.esri.com/library/userconf/proc95/to250/p241.html

Molua EL (2002) Climate variability, vulnerability and effectiveness of farm-level adaptation options: the challenges and implications for food security in rural Cameroon. J Environ Develop Econ 7(3):529-545

Molua EL (2003) Global climate change and Cameroon's agriculture: evaluating the economic impacts. Cuvillier, Göttingen

Nicholson SE (2001) Climatic and environmental change in Africa during the last two centuries. Clim Res 17:123-144

NOAA (2001) National Environmental Satellite, Data and Information Service (NESDIS). Available at: www.nesdis. noaa.gov/datainfo.html

Phillips PCB (1987) Time series regression with a unit root. Econometrica 55:277-301

Phillips PCB, Perron P (1988) Testing for a unit root in time series regression. Biometrica 75:335-346

Schmidt P, Phillips PCB (1992) LM Tests for a unit root in the presence of deterministic trends. Oxf Bull Econ Stat 54: $257-287$

Stern DI, Kaufmann RK (1997) Time series properties of global climate variables: detection and attribution of climate change. Tech Rep Work Pap Ecol Econ no 9702, Centre for Resource and Environmental Studies, Australian National University

UNEP/GEF (2000) UNEP/GEF country case studies on climate change impacts and adaptation assessments (Estonia, Pakistan, Antigua \& Barbuda, Cameroon). In: O'Brien $\mathrm{K}$ (ed) Developing strategies for climate change. Rep No. 2000:2, Center for International Climate and Environmental Research, Oslo, p 49-70. Available at: www.cicero.uio. no/media/314.pdf

Vogelsang TJ, Franses PH (2001) Testing for common deterministic trend slopes. Econometric Inst Rep 2001-16/A, Tinbergen Institute, Rotterdam. Available at: www.few. eur.nl/few/research/pubs/ei/2001/reports.htm

Wibig J, Glowicki B (2002) Trends in minimum and maximum temperature in Poland. Clim Res 20:123-133

Woodward WA, Bottone S, Gray H (1997) Improved tests for trend in time series data. J Agric Biol Environ Stat 2: 403-416

Zheng X, Basher RE (1999) Structural time series models and trend detection in global and regional temperature series. J Clim 12:2347-2358

Submitted: August 6, 2003; Accepted: December 14, 2005

Proofs received from author(s): March 17, 2006 